of the twins described comparable to the other emphasize the variability of the abnormality.

I wish to thank Mr. D. M. W. Maxwell, of Windsor, for allowing me to examine these twins and for permission to report on them.

REFERENCES

Beck, F., and Lloyd, J. B. (1966). In Advances in Teratology, edited by D. H. M. Woollam, vol. 1, p. 131. London.

Boyd, J. D. (1960). Med. Press, 243, 157.

Carey, E. J. (1919). Anat. Rec., 16, 45.
Curtis, A. H., and Helmholtz, H. F. (1911). Trans. Chic. path. Soc., 8, 127.

Hendrickx, A. G., Axelrod, L. R., and Clayborn, L. D. (1966). Nature (Lond.), 210, 958

Lenz, W. and Knapp, K. (1962). Arch. environm. Hlth, 5, 100.

Milaire, $\vec{J}$ (1965). In Organogenesis, edited by $R$. L. DeHaan and $H$. Ursprung, $\mathrm{p}$. 283. New York.

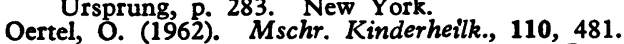

Saunders, J. W., jun., Cairns, J. M., and Gasseling, M. T. (1957). 7. Morph., io1, 57 .

Smithells, R. W. (1966). In Advances in Teratology, edited by D. H. M. Woollam, vol. 1, p. 251 . London.

Stockard, C. R. (1931). Physical Basis of Personality. New York.

Zwilling, E. (1956). Cold Spr. Harb. Symp. quant. Biol., 21, 349.

\title{
ABO Blood Groups and Polyps of the Colon*
}

\author{
THOMAS C. FLEMING, $†$ M.D.; HARVEY W. CAPLAN, $\ddagger$ M.D. ; GEORGE A. HYMAN,§ M.D. \\ F. DAVID KITCHIN, $\|$ M.D., M.R.C.P.
}

Brit. med.7., 1967, 4, 526-527

Though it appears that a significant proportion of villous adenomas or papillomas of the large bowel develop malignant properties, the debate still continues on the importance of adenomatous polyps as the sources of large-bowel cancer. Evans (1966) feels that the associations between multiple cancers of the colon and adenomatous polyps, and multiple polyps and cancer of the bowel, do not necessarily indicate an orthogenetically determined polyp-carcinoma sequence. $\mathrm{He}$ favours the view that they represent varying degrees of genetically determined large-bowel proneness to both cancer and adenoma.

With the exception of polyposis coli, no genetic locus has been associated with cancer of the large bowel or polyp formation, though Veale (1965) has postulated an unfavourable allelic modifier of the polyposis gene which in double dose produces a few adenomas of the rectum or colon. The ABO locus which is implicated in the causation of cancer of the stomach (Aird et al., 1953), multiple primary cancers (Fadhli and Dominguez, 1963 ; Tsudaka et al., 1964), and possibly chronic lymphatic leukaemia or lymphoma and carcinoma of the colon (Hyman et al., 1963), does not appear to be a factor in carcinoma of the colon.

This paper reports the ABO blood group distributions in 373 patients with polyps of the colon or rectum and an association between group $\mathrm{O}$ and papillary adenoma of the colon.

\section{Materials and Methods}

Case records of all patients seen at Columbia-Presbyterian Medical Center between 1948 and 1960 ; at Montefiore Hospital, Bronx, N.Y., between 1952 and 1959 ; and at the Bronx Veterans Hospital, Bronx, N.Y., between 1952 and 1959 who had the diagnosis of polyps of the colon or rectum were

- This work from the Department of Medicine, Columbia University College of Physicians and Surgeons, and the Medical Service of Columbia-Presbyterian Medical Center and the Francis Delafield Hospital, New York City, New York, 10032, was supported in part Hospital, New York City, New York, Service Research Grant CA02332 from the National Cancer Institute, and the Hyman Goldburg Memorial Fund.

† Surgical Intern, Bernalilio County Indian Hospital, Albuquerque, New Mexico.

₹ At present at University Hospitals, Cleveland, Ohio

Assistant Clinical Professor in Medicine, Columbia University College of Physicians and Surgeons ; Haematologist and Blood Bank Director, Francis Delafield Hospital ; Assistant Physician in MediDirector, Francis Delafield Hospial ; Assistant Physician in M.Y.

$\|$ Associate in Medicine and Human Genetics, Columbia University College of Physicians and Surgeons. checked. Only Caucasian patients whose blood types were known and whose polyps were removed and examined histologically were selected, and any family history of polyps or of carcinoma was carefully noted. For all cases from this centre the ABO blood groups were determined in the Presbyterian Hospital Blood Bank and were done on admission before transfusion. The cases totalled 317 from Columbia-Presbyterian Medical Center, 22 from Montefiore Hospital, and 34 from the Veterans Hospital. Follow-up was not complete, but $90 \%$ (335) of the patients were examined by barium meal, proctoscopy, or both to determine whether carcinoma or additional polyps had developed. During a five-year follow-up $58 \%$ (217) of the patients were seen several times. Patients were assigned to groups deperiding on pathological diagnosis, the number of polyps, and the family history.

For the purposes of this study adenomatous polyps are defined as being composed of a rounded, lobulated compact mass of branching glandular tubules, lined by columnar epithelium and supported by branching connective tissue. They are usually pedunculated, with the pedicle covered by normal mucosa (Grinnell and Lane, 1958). Papillary adenomas are defined as sessile growths, composed of innumerable branching villi clothed in stratified or pseudostratified columnar epithelium and usually covered by a coating of mucus (Grinnell and Lane, 1958).

Case records of all patients seen at Columbia-Presbyterian Medical Center between 1930 and 1966 with the diagnosis of polyposis of the colon, defined as 10 or more polyps, were checked. Of the 18 cases found 12 were examples of intestinal polyposis and seven had a positive family history. All patients with polyposis coli had their colon removed surgically and were found to have large numbers (from hundreds to thousands) of adenomatous polyps. The six patients with as few as 10 polyps have been included in the multiple polyposis group because it is thought by some (Veale, 1965 ; McConnell, 1966) that these patients may have inherited a weakly expressed polyposis gene.

As most of the patients were treated at the ColumbiaPresbyterian Medical Centre the control group was chosen from this hospital's blood bank records. Non-profit Caucasian donors at the Presbyterian Hospital Blood Bank for the year 1960 were decided to be the most appropriate control, since the few Negroes with polyps were excluded from the study. In spite of careful selection there was a higher incidence of group $\mathrm{B}$ and a lower incidence of group $\mathrm{A}$ in the Presbyterian Hospital series than in other control groups (see Table I). This 
finding may be the expression of bias inherent in a non-profit donor group which is composed of friends and relations replacing blood used in the treatment of one of their family as well as public-spirited blood donors. Nevertheless, when this control group is compared, $\mathrm{O}$ to Not-O, with the pooled control groups from other regions in the U.S.A. the heterogeneity test gives $\chi^{2}=0.114 ; 0.80>P>0.70$, and so the smaller control group has been used for the comparisons.

TABle I.-ABO Blood Groups in Control Caucasian Populations

\begin{tabular}{|c|c|c|c|c|c|}
\hline Group & $\mathbf{A}$ & B & $\mathbf{O}$ & $\mathbf{A B}$ & Total \\
\hline $\begin{array}{l}\text { Caucasian non-profit } \\
\text { donors at Presby- } \\
\text { terian Hospital in } \\
1960 \text { (group } \\
\text { chosen as overall } \\
\text { control) }\end{array}$ & $\begin{array}{r}928 \\
36.8 \%\end{array}$ & $\begin{array}{r}344 \\
13 \cdot 6 \%\end{array}$ & $\begin{array}{r}1,122 \\
44 \cdot 4 \%\end{array}$ & $\begin{array}{r}131 \\
5 \cdot 2 \%\end{array}$ & 2,525 \\
\hline $\begin{array}{l}\text { Caucasians, } \\
\text { Columbus, Ohio* }\end{array}$ & $\begin{array}{r}2,535 \\
43 \cdot 19 \%\end{array}$ & $\begin{array}{r}539 \\
9 \cdot 19 \%\end{array}$ & $\begin{array}{r}2,585 \\
44 \cdot 04 \%\end{array}$ & $\begin{array}{r}210 \\
3.58 \%\end{array}$ & 5,896 \\
\hline $\begin{array}{c}\text { Caucasians, } \\
\text { Detroit** }\end{array}$ & $\begin{array}{r}2,359 \\
41 \cdot 0 \%\end{array}$ & $\begin{array}{r}683 \\
11.9 \%\end{array}$ & $\begin{array}{r}2,396 \\
41 \cdot 8 \%\end{array}$ & $\begin{array}{r}299 \\
5 \cdot 2 \%\end{array}$ & 5,728 \\
\hline $\begin{array}{l}\text { Caucasians, } \\
\text { Massachusetts" }\end{array}$ & $\begin{array}{r}9,263 \\
39 \cdot 7 \%\end{array}$ & $\begin{array}{r}2,465 \\
10.6 \%\end{array}$ & $\begin{array}{l}10,810 \\
46 \cdot 3 \%\end{array}$ & $\begin{array}{r}794 \\
3.4 \%\end{array}$ & 23,332 \\
\hline $\begin{array}{l}\text { Caucasians, } \\
\text { Rochester, N.Y.* }\end{array}$ & $\begin{array}{r}9,937 \\
41 \cdot 8 \%\end{array}$ & $\begin{array}{r}2,394 \\
10 \cdot 1 \%\end{array}$ & $\begin{array}{l}10,562 \\
44 \cdot 4 \%\end{array}$ & $\begin{array}{r}894 \\
3.8 \%\end{array}$ & 23,787 \\
\hline $\begin{array}{l}\text { Caucasians, region } \\
\text { unspecified }\end{array}$ & $\begin{array}{r}8,200 \\
41 \%\end{array}$ & $\begin{array}{r}2,000 \\
10 \%\end{array}$ & $\begin{array}{l}9,000 \\
45 \%\end{array}$ & $\begin{array}{l}800 \\
4 \%\end{array}$ & $\begin{array}{c}20,000 \\
.\end{array}$ \\
\hline $\begin{array}{l}\text { Ranges of control } \\
\text { populations }\end{array}$ & $\begin{array}{r}36 \cdot 8- \\
43 \cdot 2 \%\end{array}$ & $\begin{array}{r}9 \cdot 2- \\
13 \cdot 6 \%\end{array}$ & $\begin{array}{l}41 \cdot 8- \\
46 \cdot 3 \%\end{array}$ & $\begin{array}{r}3 \cdot 4-2 \\
5 \cdot 2 \%\end{array}$ & \\
\hline Average & $41 \cdot 3 \%$ & $10.3 \%$ & $44.5 \%$ & $3.8 \%$ & \\
\hline
\end{tabular}

\section{Results}

The results (Table II) and the statistical analysis (Table III) are summarized below.

TABLE II.-ABO Blood Groups of Patients with Polyps

\begin{tabular}{|c|c|c|c|c|c|c|c|c|c|}
\hline & \multicolumn{2}{|c|}{$\mathbf{A}$} & \multicolumn{2}{|c|}{ B } & \multicolumn{2}{|c|}{$\mathbf{A B}$} & \multicolumn{2}{|c|}{$\mathbf{O}$} & \multirow{2}{*}{ Total } \\
\hline & No. & $\%$ & No. & $\%$ & No. & $\%$ & No. & $\%$ & \\
\hline A. All polyps & 137 & 37 & 48 & 13 & 17 & 5 & 171 & 46 & 373 \\
\hline$\left[\begin{array}{c}\text { (1) Adenomatous polyps } \\
\text { only }\end{array}\right.$ & 128 & 39 & 43 & 13 & 16 & 5 & 139 & 43 & 326 \\
\hline B. $\left\{\begin{array}{l}\text { (2) One adenomatons } \\
\text { polyp }\end{array}\right.$ & 76 & 38 & 25 & 13 & 9 & 5 & 87 & 44 & 197 \\
\hline $\begin{array}{l}\text { (3) Two or more adeno- } \\
\text { matous polyps } \\
\text { C. Papillary adenomas oniy } \\
\text { D. Both adenomatous and }\end{array}$ & $\begin{array}{r}52 \\
2\end{array}$ & $\begin{array}{l}40 \\
10\end{array}$ & $\begin{array}{r}18 \\
3\end{array}$ & $\begin{array}{l}14 \\
14\end{array}$ & $\begin{array}{l}7 \\
0\end{array}$ & $\begin{array}{l}5 \\
0\end{array}$ & $\begin{array}{l}52 \\
16\end{array}$ & $\begin{array}{l}40 \\
76\end{array}$ & $\begin{array}{r}129 \\
21\end{array}$ \\
\hline $\begin{array}{l}\text { papillary polyps in same } \\
\text { patient .. } \\
\text { E. All patients with papillary }\end{array}$ & 7 & 29 & 2 & 8 & 1 & 4 & 16 & 62 & 26 \\
\hline $\begin{array}{ll}\text { adenoma }(C+D) & \ldots \\
\text { F. Polyposis coli } & \ldots\end{array}$ & $\begin{array}{l}9 \\
6\end{array}$ & $\begin{array}{l}19 \\
33\end{array}$ & $\begin{array}{l}5 \\
1\end{array}$ & $\begin{array}{r}11 \\
6\end{array}$ & $\begin{array}{l}1 \\
0\end{array}$ & $\begin{array}{l}2 \\
0\end{array}$ & $\begin{array}{l}32 \\
11\end{array}$ & $\begin{array}{l}68 \\
61\end{array}$ & $\begin{array}{l}47 \\
18\end{array}$ \\
\hline
\end{tabular}

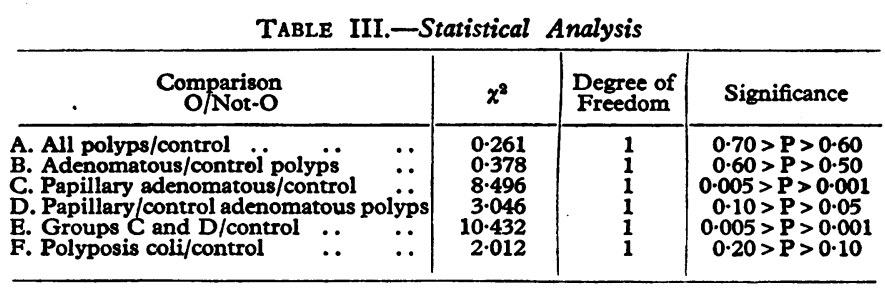

A. Three hundred and seventy-three patients had one or more polyps, and there was no statistical difference in the distribution of blood groups between these and the controls.

B. Three hundred and twenty-six patients had one or more adenomatous polyps, and there was no statistical difference in the distribution of blood groups between these and the controls.

C. Twenty-one patients had one or more papillary adenomas, and $16(76 \%)$ of these were blood group $O$. This increase was statistically significant $(P>0.001)$ when compared with the control group.

D. Twenty-six patients had both papillary adenomas and adenomatous polyps, and $16(62 \%)$ of these were type $O$. This finding was not statistically significant.
E. Groups $\mathrm{C}$ and $\mathrm{D}$ can be combined (heterogeneity test $C+D$ gives $\chi^{2}=0.57,0.50>P>0.40$ ) to make a group of 47 patients, all of whom had at least one papillary adenoma. Thirty-two $(68 \%)$ of these patients were group $O$, and this finding was significant $(P<0.005)$. If the combined control group from other regions in the U.S.A. is used for comparison $\chi^{2}=10.958, P<0.001$.

F. Eighteen patients had multiple polyposis, and $11(61 \%)$ of these were type $O$, but this increase was not statistically significant.

G. Only 16 of 373 patients with polyps had a family history of colonic carcinoma or polyps of the colon. Two of these had multiple polyposis and 13 had one or more adenomatous polyps.

\section{Discussion}

Analysis of the data indicates that the ABO blood group distributions in patients with polyps of the colon are not significantly different from control populations except in the subdivision of papillary adenomas.

The data suggest that papillary adenomas can be distinguished from adenomatous polyps, familial and non-familial, since the $\mathrm{ABO}$ locus is involved in the papillary adenoma group. Furthermore, this finding indicates that papillary adenomas have a different cause from adenomatous polyps in that the ABO locus is one of the polygenic factors conditioning the susceptibility to the disease.

The limitation of a study of this type is well recognized, particularly in view of the small number of patients and difficulty in selecting a proper control group because of the racial differences in blood type in the heterogeneous population of New York City. We hope that this study will stimulate further investigations of the $\mathrm{ABO}$ blood groups in patients with papillary adenomas and adenomatous polyps of the colon in other populations.

\section{Summary}

The ABO blood groups have been determined in 373 patients with polyps of the colon, divided into adenomatous polyps and familial and non-familial and papillary adenomas. In the two subdivisions of the adenomatous polyps the blood group distributions did not differ from the control group, but a significant excess of blood group $O$ was found in the patients with papillary adenomas. This finding indicates that papillary adenomas have a different cause from adenomatous polyps and supports the separation, on histological and clinical grounds, of the two kinds of growths.

We wish to thank the following colleagues in Columbia University College of Physicians and Surgeons for their invaluable assistance in the preparation of the manuscript: Dr. Nathan Lane and Dr. Rafael Lattes, Department of Surgical Pathology; and the staff of the Department of Statistics, Columbia University School of Public Health. We also wish to thank the Record Departments of the Montefiore and Bronx Veterans Hospitals for their assistance during the performance of the studies.

\section{REFERENCES}

Aird, I., Bentall, H. H., and Roberts, J. A. F. (1953). Brit. med. F., 1,

Evans, R. W. (1966). Histological Appearances of Tumours, 2nd ed. Edinburgh.

Fadhli, H. A., and Dominguez, R. (1963). F. Amer. med. Ass., 185, 757.

Grinnell, R. S., and Lane, N. (1958). Int. Abstr. Surg., 106, 519.

Hyman, G. A., Ultmann, J. E., and Slanetz, C. A. (1963). F. Amer. med. Ass., 186, 1053.

McConnell, R. B. (1966). The Genetics of Gastro-Intestinal Disorders, pp. 147-169. London.

Tsukada, Y., Moore, R. H., Bross, I. D. J., Pickren, J. W., and Cohen, E. (1964). Cancer (Philad.), 17, 1229.

Veale, A. M. O. (1965). Intestinal Palyposis. Eugenics Laboratory Memoirs, XL. London. 